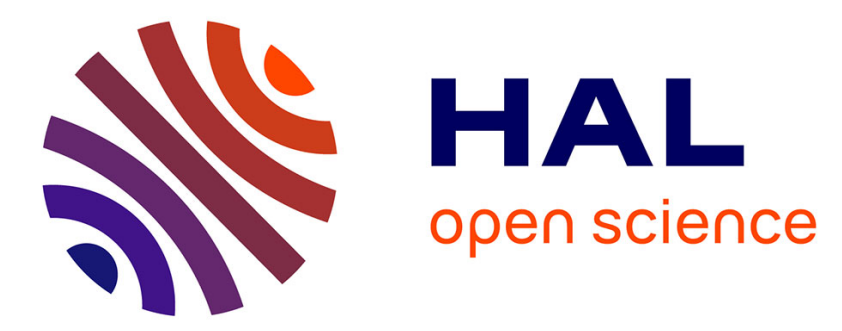

\title{
High variability in migration and wintering strategies of brown skuas (Catharacta antarctica lonnbergi) in the Indian Ocean
}

Karine Delord, Yves Cherel, Christophe Barbraud, Olivier Chastel, Henri Weimerskirch

\section{To cite this version:}

Karine Delord, Yves Cherel, Christophe Barbraud, Olivier Chastel, Henri Weimerskirch. High variability in migration and wintering strategies of brown skuas (Catharacta antarctica lonnbergi) in the Indian Ocean. Polar Biology, 2018, 41 (1), pp.59-70. 10.1007/s00300-017-2169-1 . hal-01848711

\section{HAL Id: hal-01848711 \\ https://hal.science/hal-01848711}

Submitted on 25 Jul 2018

HAL is a multi-disciplinary open access archive for the deposit and dissemination of scientific research documents, whether they are published or not. The documents may come from teaching and research institutions in France or abroad, or from public or private research centers.
L'archive ouverte pluridisciplinaire HAL, est destinée au dépôt et à la diffusion de documents scientifiques de niveau recherche, publiés ou non, émanant des établissements d'enseignement et de recherche français ou étrangers, des laboratoires publics ou privés. 
Dear Author,

Here are the proofs of your article.

- You can submit your corrections online, via e-mail or by fax.

- For online submission please insert your corrections in the online correction form. Always indicate the line number to which the correction refers.

- You can also insert your corrections in the proof PDF and email the annotated PDF.

- For fax submission, please ensure that your corrections are clearly legible. Use a fine black pen and write the correction in the margin, not too close to the edge of the page.

- Remember to note the journal title, article number, and your name when sending your response via e-mail or fax.

- Check the metadata sheet to make sure that the header information, especially author names and the corresponding affiliations are correctly shown.

- Check the questions that may have arisen during copy editing and insert your answers/ corrections.

- Check that the text is complete and that all figures, tables and their legends are included. Also check the accuracy of special characters, equations, and electronic supplementary material if applicable. If necessary refer to the Edited manuscript.

- The publication of inaccurate data such as dosages and units can have serious consequences. Please take particular care that all such details are correct.

- Please do not make changes that involve only matters of style. We have generally introduced forms that follow the journal's style.

Substantial changes in content, e.g., new results, corrected values, title and authorship are not allowed without the approval of the responsible editor. In such a case, please contact the Editorial Office and return his/her consent together with the proof.

- If we do not receive your corrections within $\mathbf{4 8}$ hours, we will send you a reminder.

- Your article will be published Online First approximately one week after receipt of your corrected proofs. This is the official first publication citable with the DOI. Further changes are, therefore, not possible.

- The printed version will follow in a forthcoming issue.

\section{Please note}

After online publication, subscribers (personal/institutional) to this journal will have access to the complete article via the DOI using the URL: http://dx.doi.org/[DOI].

If you would like to know when your article has been published online, take advantage of our free alert service. For registration and further information go to: http://www.link.springer.com.

Due to the electronic nature of the procedure, the manuscript and the original figures will only be returned to you on special request. When you return your corrections, please inform us if you would like to have these documents returned. 


\section{Metadata of the article that will be visualized in OnlineFirst}

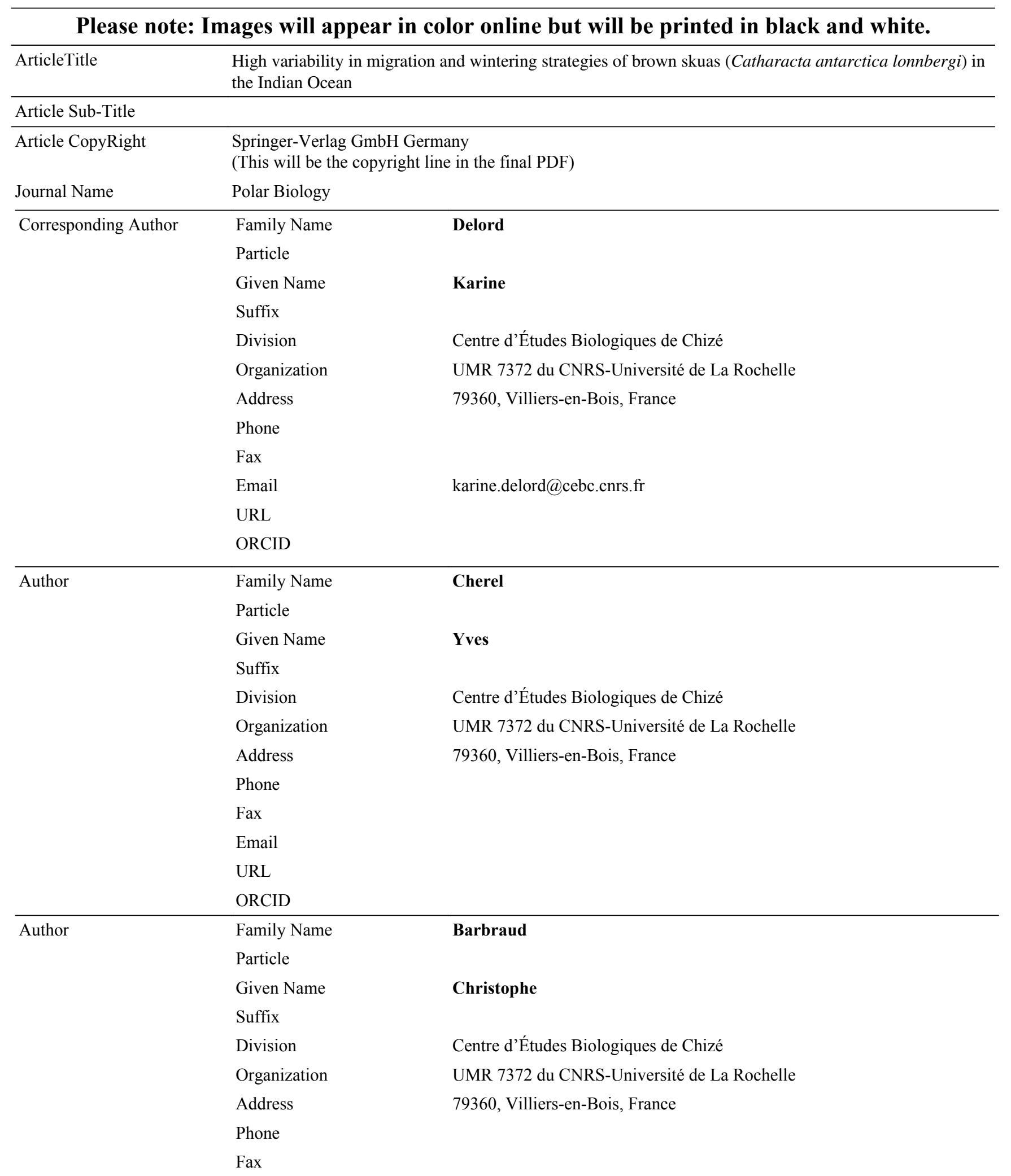


Email

URL

ORCID

\begin{tabular}{|c|c|c|}
\hline \multirow[t]{12}{*}{ Author } & Family Name & Chastel \\
\hline & Particle & \\
\hline & Given Name & Olivier \\
\hline & Suffix & \\
\hline & Division & Centre d'Études Biologiques de Chizé \\
\hline & Organization & UMR 7372 du CNRS-Université de La Rochelle \\
\hline & Address & 79360, Villiers-en-Bois, France \\
\hline & Phone & \\
\hline & Fax & \\
\hline & Email & \\
\hline & URL & \\
\hline & ORCID & \\
\hline \multirow[t]{12}{*}{ Author } & Family Name & Weimerskirch \\
\hline & Particle & \\
\hline & Given Name & Henri \\
\hline & Suffix & \\
\hline & Division & Centre d’Études Biologiques de Chizé \\
\hline & Organization & UMR 7372 du CNRS-Université de La Rochelle \\
\hline & Address & 79360, Villiers-en-Bois, France \\
\hline & Phone & \\
\hline & Fax & \\
\hline & Email & \\
\hline & URL & \\
\hline & ORCID & \\
\hline
\end{tabular}

\begin{tabular}{lll}
\hline & Received & \\
Schedule & Revised & 24 October 2016 \\
& Accepted & 29 June 2017 \\
\hline
\end{tabular}

Abstract

Movements of brown skuas (Catharacta antarctica lonnbergi) originating from two populations in the southern Indian Ocean were studied during the nonbreeding period using geolocation. A total of 33 individuals were equipped resulting in 34 annual tracks recovered from 50 deployments. Brown skuas varied extensively in their post-breeding movements, from true long range migrations to reach distant wintering zones, to short movements in the vicinity of breeding grounds. Overall, brown skuas migrated northward to overwinter in different areas in the southern hemisphere; individuals remained in the Indian Ocean, except two that overwintered in the Benguela Current (Atlantic Ocean). Wintering grounds were generally situated in productive dynamic upwelling waters or frontal systems. Brown skuas avoided the less productive area of the South Subtropical Gyre in the Central Indian Ocean. Individuals clearly differed in migratory strategies, targeting areas in a continuum from the sub-Antarctic to the tropics. Interindividual differences were not sex-dependent. The migration dates varied between sexes with females leaving the breeding sites earlier and returning later compared to males. The duration of migration depended on wintering area and sex. Males had shorter migrations than females, regardless of the wintering area. Isotopic signatures clearly indicated that birds moulted in the wintering area and during migration. The low $\delta{ }^{15} \mathrm{~N}$ values of feathers that grew in mixed subtropical-sub-Antarctic waters suggest that skuas fed on low trophic level prey in these areas. The origin and consequences of such strong interindividual variation in migratory strategies requires further investigation.

Keywords (separated by '-') Activity - Feather - Geolocator - Intraspecific strategies - Phenology - Stable isotopes 

contains supplementary material, which is available to authorized users. 


\title{
2 High variability in migration and wintering strategies of brown 3 skuas (Catharacta antarctica lonnbergi) in the Indian Ocean
}

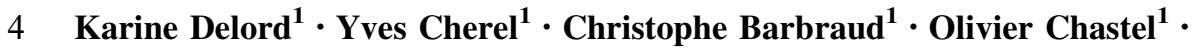 \\ 5 Henri Weimerskirch ${ }^{1}$
}

Electronic supplementary material The online version of this article (doi:10.1007/s00300-017-2169-1) contains supplementary material, which is available to authorized users.

\begin{abstract}
Movements of brown skuas (Catharacta antarctica lonnbergi) originating from two populations in the southern Indian Ocean were studied during the nonbreeding period using geolocation. A total of 33 individuals were equipped resulting in 34 annual tracks recovered from 50 deployments. Brown skuas varied extensively in their post-breeding movements, from true long range migrations to reach distant wintering zones, to short movements in the vicinity of breeding grounds. Overall, brown skuas migrated northward to overwinter in different areas in the southern hemisphere; individuals remained in the Indian Ocean, except two that overwintered in the Benguela Current (Atlantic Ocean). Wintering grounds were generally situated in productive dynamic upwelling waters or frontal systems. Brown skuas avoided the less productive area of the South Subtropical Gyre in the Central Indian Ocean. Individuals clearly differed in migratory strategies, targeting areas in a continuum from the sub-Antarctic to the tropics. Inter-individual differences were not sex-dependent. The migration dates varied between sexes with females leaving the breeding sites earlier and returning later compared to males. The duration of migration depended on wintering area and sex. Males had shorter migrations than females, regardless of the wintering area. Isotopic signatures clearly indicated that birds moulted in the wintering area and during migration. The low $\delta^{15} \mathrm{~N}$
\end{abstract}

\section{Karine Delord}

karine.delord@cebc.cnrs.fr

1 Centre d'Études Biologiques de Chizé, UMR 7372 du CNRSUniversité de La Rochelle, 79360 Villiers-en-Bois, France values of feathers that grew in mixed subtropical-subAntarctic waters suggest that skuas fed on low trophic level prey in these areas. The origin and consequences of such strong inter-individual variation in migratory strategies requires further investigation.

Keywords Activity · Feather - Geolocator - Intraspecific strategies $\cdot$ Phenology $\cdot$ Stable isotopes

\section{Introduction}

Migration is commonly considered to be a response to seasonal variation in the environment and particularly to prey availability (Jessopp et al. 2013). Seabirds are central place foragers during breeding but can range over much larger areas in search of food outside the breeding period. Migration often necessitates large-scale movements beyond the breeding home range and is an essential component of the life-history of flying seabirds (Shaffer et al. 2006; Egevang et al. 2010; Weimerskirch et al. 2014). Migration strategies of seabirds can differ markedly, exhibiting intraspecific variations linked to population, sex or age (Guilford et al. 2009; Dias et al. 2011; Fijn et al. 2013). Individuals from the same breeding colony could migrate using different routes, thereby reaching distant and distinct wintering grounds (Yamamoto et al. 2010; Weimerskirch et al. 2015a, b). Timing for the outbound or the inbound movements could also differ between individuals and the sexes, (Yamamoto et al. 2010; Hedd et al. 2014; Thiebot et al. 2014). Hence, describing and understanding the individual differences in migration strategy that may impact winter survival of individuals is a key issue in population dynamics of long-lived species

$\begin{array}{lll}\text { Journal : Large 300 } & \text { Dispatch : 5-7-2017 } & \text { Pages : 12 } \\ \text { Article No. : } \mathbf{2 1 6 9} & \square \text { LE } & \square \text { TYPESET } \\ \text { MS Code : POBI-D-16-00207 } & \sim_{\text {CP }} & \checkmark \text { DISK }\end{array}$


(Barbraud and Weimerskirch 2003; Frederiksen et al. 2008; Reiertsen et al. 2014).

The identification of migration strategies is furthermore crucial to understand how individuals are differently affected by climate change (Weimerskirch et al. 2012), pollution, particularly oiling (Montevecchi et al. 2012a, b), interaction with fisheries including the associated incidental bycatch (Phillips et al. 2005; Watkins et al. 2008; Maree et al. 2014) and exposure to contaminants (Blévin et al. 2013; Leat et al. 2013; Carravieri et al. 2014a). Individual responses to environmental variability or to anthropogenic factors can have strong implications in terms of survival and population dynamics (Harris et al. 2013; Goutte et al. 2014). Individuals, from the same or different populations, might share wintering areas and experience similar threats (Gonzalez-Solis et al. 2007; Frederiksen et al. 2012; Tranquilla et al. 2014), or individuals might have different strategies, resulting in differences in threat exposure (Rayner et al. 2011; Hedd et al. 2012; Carey et al. 2014).

Large skuas (Stercorariidae, Catharacta sp.) are colonial seabirds that breed mainly in the Southern Ocean and in Antarctica (except one Northern Atlantic species). A high degree of interspecific variation exists in migration strategies in skuas, even within species and populations (Phillips et al. 2007; Kopp et al. 2011; Weimerskirch et al. 2015a, b; Krietsch et al. 2017). However, few studies on migration movements of skuas have been conducted and intraspecific variations in migration patterns and in wintering areas remain poorly understood. For species that employ specialized predatory strategies (such as skuas), understanding how individuals can adjust their foraging behaviour to changing conditions to fulfil their life-history needs is a cornerstone of their ecology. The reason for such high variation is unknown, but it should clearly have different fitness consequences for individuals (because the different areas might differ in their productivity and in the experienced threats).

The aim of this study was to contribute such information for two brown skua populations (Catharacta antarctica lonnbergi, Mathews, 1912) breeding in the sub-Antarctic French Southern Territories. The brown skua is a longlived seabird that mainly breeds on sub-Antarctic islands and the Antarctic Peninsula. The diet of brown skuas is relatively well documented during the breeding season, with birds feeding on local abundant resources; they often specialize as predators or scavengers of petrels and penguins (Furness 1987; Olsen and Larsson1997). However, the diet and foraging ecology of brown skuas remain poorly known outside the breeding season (Furness 1987). Food availability usually varies throughout the year and is most likely a driver of migration and wintering strategies (Lack 1968; Alerstam et al. 2003). The timing of the migration is expected to be synchronized with the phenology of the prey species, especially with migratory species, to avoid a mistiming in breeding cycles (Visser and Both 2005). The nonbreeding distribution of brown skuas is only known for South Georgia (Phillips et al. 2007; Carneiro et al. 2016) and King George Island (Krietsch et al. 2017). To date, the wintering ranges for Southern Indian Ocean populations have been inferred primarily from at-sea sightings or recoveries of ringed birds. This information suggests that during the nonbreeding period some individuals stay close to their breeding range, while others are migratory or dispersive (Eklund 1961; Olsen and Larsson 1997). Some individuals winter around Australia, with two ring recoveries of Kerguelen birds there (Higgins and Davies 1996).

The present study focuses on the intraspecific comparison of migration strategies, wintering ranges, activity patterns and diet of two populations of brown skuas in the Southern Indian Ocean by combining tracking (geolocators) and stable isotope analyses. Using biotelemetry data, we investigated whether (1) individuals vary in their migratory behaviour, (2) sexes differ in their migration timing and wintering areas, and (3) individuals modify their activity patterns between the breeding, migration and nonbreeding period. We hypothesized that a shift might be accompanied by modification of the activity pattern (i.e. time spent on the water recorded by the geolocators), concomitant with a change in the isotopic signature between the two periods, similar to recent results for the south polar skua (Weimerskirch et al. 2015a, b).

\section{Methods}

Brown skuas were studied on two sub-Antarctic islands in the southern Indian Ocean: Possession Island $\left(46^{\circ} 25^{\prime} \mathrm{S}\right.$, $\left.51^{\circ} 45^{\prime} \mathrm{E}\right)$ in the Crozet archipelago and Mayes Island $\left(49^{\circ} 28^{\prime} \mathrm{S}, 69^{\circ} 57^{\prime} \mathrm{E}\right)$ in the Kerguelen archipelago. Tracking data were used to characterise the at-sea distribution of adults during their breeding and nonbreeding periods. Global location sensing (GLS) loggers (British Antarctic Survey, Cambridge) were deployed on adults during the breeding season (2008-2009 and 2011-2012 at Kerguelen; $n=40$ and 2010-2011 at Crozet; $n=10$ ). GLS loggers (Mk5, Mk15) weighed 3.6 and $2.5 \mathrm{~g}$, respectively, i.e. $\approx 0.14 \%$ of body mass and well below the recommended threshold of 3\% of body mass (Phillips et al. 2003). These were mounted on plastic or metal leg bands. Adults were captured on the nest during the breeding season (brooding or chick rearing stage). Sex of the birds, except those from Crozet, was determined using molecular methods (Blanchard et al. 2007) ( $n=29 ; 13$ males and 16 females). Processing of the GLS daylight data was carried out as described previously (Péron et al. 2010). Migration timing 
was determined by combined visual examination of movement and activity data; outward migration started from the first directional movement (followed by several consecutive days with directional flight), while the final nonbreeding location was the last location in the nonbreeding area before a sustained period of directional movement towards the breeding colony. Birds were considered to be wintering from the end of the outward migration in February to April, to the onset of the return migration in the following August. The breeding success of the tracked individuals was unknown.

GLS data allow long-term (several years) latitude and longitude estimation from daylight measurements, albeit although with a lower accuracy $(186 \pm 114 \mathrm{~km}$; Phillips et al. 2004) than satellite transmitters (Wilson et al. 1992). Loggers measured daylight level intensity every $60 \mathrm{~s}$ and the maximum intensity for each $10 \mathrm{~min}$ is recorded. An internal clock allows estimation of the latitude based on day length and longitude based on the timing of local midday with respect to Coordinated Universal Time (Afanasyev 2004). Daylight data recorded by GLS were analysed using a standardized procedure for flying seabirds (Phillips et al. 2004) to provide two locations per day. Thresholds $(h=4)$ in the light curves were used to determine sunrise and sunset. Locations fixes were calculated from daylight data using BASTrak software (British Antarctic Survey 2009). During a 1-2 weeks period around the equinoxes (20-21 March and 22-23 September), latitude cannot be estimated accurately (Wilson et al. 1992). Spatial distribution of brown skuas during the interbreeding period was investigated by producing $25 \%$ utilization distributions (UDs) for each individual, using kernel analysis with a cell size of $2^{\circ} \times 2^{\circ}$ and a fixed smoothing parameter $(h)$ of $2^{\circ}$. Both $h$ value and grid cell size were based on the mean accuracy of the devices. Spatial analyses were performed using the "adehabitatHR" $\mathrm{R}$ package (Calenge 2006).

Immersion data indicated the number of $3 \mathrm{~s}$ periods during 10 min blocks when the sensor on the unit was immersed in saltwater and raw values ranged from 0 (no immersion) to 200 (permanently immersed). The GLS raw immersion data were processed as described previously (Péron et al. 2010) to estimate the daily percentage of time spent on the sea surface (activity) separately for diurnal and nocturnal periods (based on local sunset and sunrise times derived by analysis of the daylight curves processed using the BASTrak software package). The mean percentage of time spent on the water (wet) was calculated daily for each period (migration and wintering) to provide information on seasonal variation in foraging behaviour. Conversely, the time spent dry is generally interpreted as flight (particularly outside the breeding period), and therefore could be assumed not to be foraging. The duration of daylight and darkness each day (consecutive light and dark period) was assessed directly from the logger daylight data. Loggers also recorded sea surface temperature (SST) when the logger was immersed for more than $10 \mathrm{~min}$. The average SST recorded monthly was used as an indicator of the water masses where the birds foraged during the nonbreeding period.

We then fitted generalized linear models (GLMs) to investigate the effects of sex, wintering location (three different water masses sensu Longhurst (2007): subtropical, tropical or sub-Antarctic) and their interaction on migration schedules (date of departure, date of arrival and duration) using a Poisson distribution. We selected only one track for the bird tracked over two consecutive years to prevent pseudo-replication. General linear mixed-effects models (GLMMs), fitted in the lme4 package (Zuur et al. 2010), were used to model activity patterns (daily proportion of time spent on the water during daytime or during darkness). Sex, wintering location, month (independent variables) and two by two interactions were included as fixed effects. Individual identity was fitted as a random effect to account for pseudo-replication, as the same individual could contribute several values. Model assumptions were visually validated based on normalized residuals, following the protocol presented by Zuur et al. (2010). Unsexed individuals were excluded from the dataset. Due to sample size, year could not be used as a fixed factor in the models. The effect of breeding colony could not be included due to small sample size for the Crozet population. Models were ranked using the Akaike Information Criterion (AIC) and Akaike weights (Burnham and Anderson 2002). The model with the lowest AIC was considered the best model. When $\triangle \mathrm{AIC}$ between models was $<2$, the models were considered equally good descriptors of the data and we chose the most parsimonious model-that with the lowest number of parameters. Spatial and statistical analyses were performed using R 2.15.3 (R Development Core Team 2013).

Following (Jaeger et al. 2009), carbon and nitrogen stable isotopes ratios $\left(\delta^{13} \mathrm{C}\right.$ and $\delta^{15} \mathrm{~N}$, respectively) were measured on four different fully grown body feathers from the lower back. Feathers were collected upon recapture of each individual bird, thus corresponding to the previous moulting period at sea recorded by the GLS. In seabirds, including skuas, feather isotope values represent the foraging habitat $\left(\delta^{13} \mathrm{C}\right)$ and diet/trophic position $\left(\delta^{15} \mathrm{~N}\right)$ during the nonbreeding period because adult birds replace their plumage at that time (Higgins and Davies 1996; Cherel et al. 2008b; but see Graña Grilli and Cherel 2017). To verify that skuas moulted body feathers outside the breeding period, ten large chicks from Kerguelen Islands were feather sampled as control birds reflecting the skua diet during the summer breeding period. At that time 
brown skuas from Mayes Island prey upon seabirds on land, mainly blue petrels (Mougeot et al. 1998), a small Procellariiforme that forages at sea in southern Antarctic waters (Cherel et al. 2014). A single chick body feather was used for isotopic analyses, because chick feathers grow almost synchronously and thus present low inter-feather $\delta^{13} \mathrm{C}$ and $\delta^{15} \mathrm{~N}$ variations (Carravieri et al. 2014b). Feather preparation and isotopic analyses were detailed by (Jaeger et al. 2009). In brief, feathers were cleaned using a 2:1 chloroform: methanol solution and then oven dried for $48 \mathrm{~h}$ at $50{ }^{\circ} \mathrm{C}$. Each whole body feather was homogenized by cutting it with scissors into small fragments and a subsample of $\sim 0.3 \mathrm{mg}$ was packed into tin containers for stable isotope analysis. The relative abundances of carbon and nitrogen isotopes were determined with a continuous flow mass spectrometer (Thermo Scientific Delta V Advantage) coupled to an elemental analyzer (Thermo Scientific Flash EA 1112). Results are presented in the usual $\delta$ notation relative to Vienna PeeDee Belemnite and atmospheric $\mathrm{N}_{2}$ for $\delta^{13} \mathrm{C}$ and $\delta^{15} \mathrm{~N}$, respectively. Replicate measurements of internal laboratory standards (acetanilide) indicated measurement errors $<0.15 \%$ for both $\delta^{13} \mathrm{C}$ and $\delta^{15} \mathrm{~N}$ values.

For statistical analyses, feather $\delta^{13} \mathrm{C}$ and $\delta^{15} \mathrm{~N}$ values were either grouped at the individual level (wintering zones) or at the feather level (moulting zone) (Table 1). In the former analysis, isotopic values of the four feathers per bird were assigned to the main wintering zone identified by the GLS data of the corresponding individual (tropical, subtropical and sub-Antarctic). In the latter analysis, each single body feather was tentatively assigned to a moulting zone (Weimerskirch et al. 2015a, b). We first looked at the GLS tracks of birds that wintered in only one marine area to assign the corresponding feather isotope values to that area. We then carefully examined the feather isotope values of skuas that spent the nonbreeding period in more than one area to correctly assign their isotopic values. We were unable to reliably assign isotopic values to a wintering area for a few feathers using this 2-step protocol (see 'Unknown' in Table 1).

\section{Results}

A total of 34 successful GLS deployments (Crozet, $n=5$; Kerguelen, $n=29 ; 1$ individual from Crozet was tracked over two successive years and returned to the same arearesults not presented) were made on 33 individuals. The GLS recovery rates varied from $40 \%$ at Crozet to $73 \%$ at Kerguelen. The loggers provided simultaneous records of location and immersion data during 34 annual tracks, which were mainly located within the Indian Ocean (Fig. 1). Body feathers were collected from 19 adult brown skuas ( 9 females and 10 males) from Kerguelen Islands only.

Table 1 Isotopic niches of brown skuas (Catharacta antarctica lonnbergi) according to individual wintering zones and to feather moulting zones (see text)

\begin{tabular}{|c|c|c|c|c|c|}
\hline Wintering areas and habitats & $\begin{array}{l}\text { Individuals } \\
(n)\end{array}$ & $\begin{array}{l}\text { Body feathers } \\
(n)\end{array}$ & $\begin{array}{l}\text { Feather } \delta^{13} \mathrm{C} \\
(\%)\end{array}$ & $\begin{array}{l}\text { Feather } \delta^{15} \mathrm{~N} \\
(\%)\end{array}$ & $\begin{array}{l}\mathrm{C}: \mathrm{N} \text { mass } \\
\text { ratios }\end{array}$ \\
\hline \multicolumn{6}{|l|}{ Wintering zones } \\
\hline Tropical & 7 & 28 & $-17.4 \pm 1.5^{\mathrm{a}}$ & $11.2 \pm 2.2^{\mathrm{a}}$ & $3.14 \pm 0.02$ \\
\hline Subtropical & 5 & 19 (1 outlier) & $-18.3 \pm 1.2^{\mathrm{b}}$ & $12.5 \pm 2.2^{\mathrm{b}}$ & $3.15 \pm 0.02$ \\
\hline Sub-Antarctic & 7 & 27 ( 1 outlier $)$ & $-18.3 \pm 0.6^{\mathrm{b}}$ & $8.5 \pm 0.6^{\mathrm{c}}$ & $3.14 \pm 0.01$ \\
\hline Chicks (Kerguelen) & 10 & 10 & $-21.5 \pm 0.3^{\mathrm{c}}$ & $11.1 \pm 0.2^{\mathrm{a}, \mathrm{b}}$ & $3.17 \pm 0.01$ \\
\hline \multicolumn{6}{|l|}{ Moulting zones } \\
\hline Madagascar & 2 & 7 & $-15.7 \pm 0.1^{\mathrm{a}}$ & $13.4 \pm 1.0^{\mathrm{a}}$ & $3.14 \pm 0.02$ \\
\hline Java & 2 & 3 & $-15.8 \pm 0.1^{\mathrm{a}}$ & $13.0 \pm 0.2^{\mathrm{a}, \mathrm{d}, \mathrm{f}}$ & $3.13 \pm 0.01$ \\
\hline West Australia & 2 & 5 & $-17.7 \pm 0.7^{\mathrm{b}}$ & $11.7 \pm 0.9^{\mathrm{b}, \mathrm{e}, \mathrm{f}}$ & $3.14 \pm 0.01$ \\
\hline Southern Australia & 4 & 9 & $-18.0 \pm 1.2^{\mathrm{b}}$ & $14.1 \pm 1.2^{\mathrm{a}}$ & $3.16 \pm 0.01$ \\
\hline Subtropical and sub-Antarctic & 13 & 37 & $-18.2 \pm 0.6^{\mathrm{b}}$ & $8.5 \pm 0.6^{\mathrm{c}}$ & $3.14 \pm 0.02$ \\
\hline Sub-Antarctic & 6 & 7 & $-19.9 \pm 0.9^{\mathrm{c}}$ & $12.3 \pm 1.6^{\mathrm{b}, \mathrm{d}}$ & $3.15 \pm 0.02$ \\
\hline Unknown & 3 & 8 & - & - & - \\
\hline Chicks (Kerguelen) & 10 & 10 & $-21.5 \pm 0.3^{\mathrm{c}}$ & $11.1 \pm 0.2^{\mathrm{e}}$ & $3.17 \pm 0.01$ \\
\hline
\end{tabular}

Note that birds may moult in several different zones. Within wintering or moulting zones, values sharing the same superscript letters are not significantly different at the 0.05 level. Values are mean $\pm \mathrm{SD}$

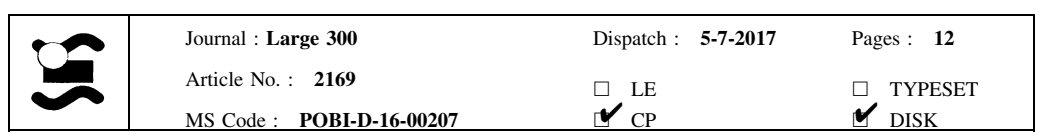




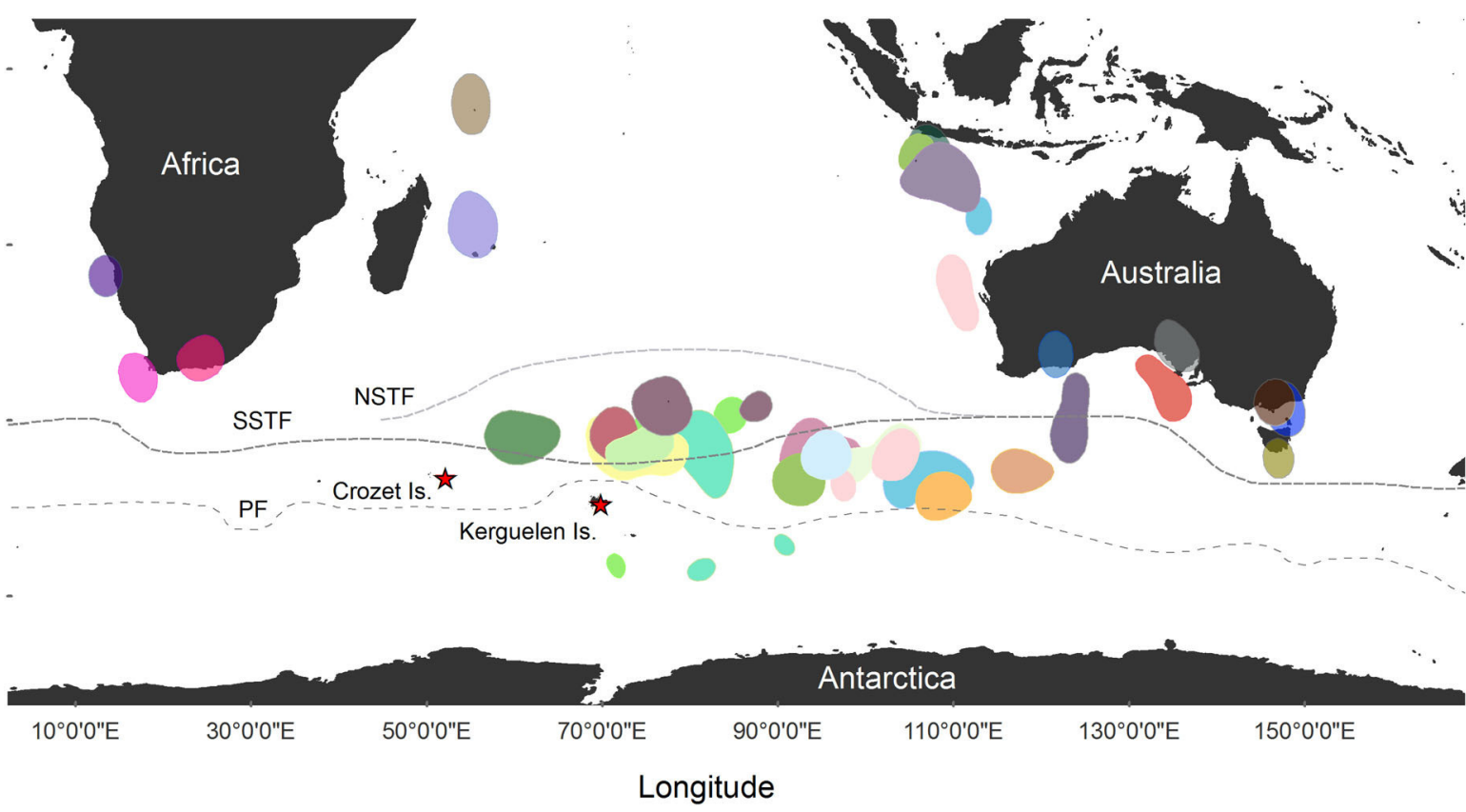

$0^{\circ} 0^{\prime} 0^{\prime \prime}$ $20^{\circ} 0^{\prime} 0^{\prime S}$

Fig. 1 Kernel densities or utilization distributions (25\%) of individual adult brown skuas (Catharacta antarctica lonnbergi) during the inter-breeding period. Individual brown skuas from Crozet $(n=5$,

\section{Movements and activity}

Brown skuas showed extensive variation in their postbreeding movements, from true long range migrations to distant wintering zones, to short movements near breeding grounds (Fig. 1). Wintering zones of brown skuas from Kerguelen and Crozet Islands (which are located $\sim 1400 \mathrm{~km}$ apart) overlapped considerably (Fig. 1). All individuals overwintered in the southern hemisphere, remaining in the Indian Ocean $\left(10^{\circ} \mathrm{E}-150^{\circ} \mathrm{E}\right)$, except two individuals that overwintered in the Benguela Current (Atlantic Ocean). At the end of the breeding season adult skuas left the breeding grounds typically to move northwards (Online Resource Fig S1). Skuas undertook their migration to wintering areas over three different water masses (sensu Longhurst (2007). Each bird wintered within a single area: (i) in the tropics, in waters off Java, the Mascareignes Region and the Seychelles Archipelago (SST in July: $25.8 \pm 2.2{ }^{\circ} \mathrm{C}$ ), (ii) in the subtropics, in waters off Australia or in the Benguela Current System (north of the northern subtropical front, $15.4 \pm 2.2{ }^{\circ} \mathrm{C}$ ), or (iii) in subAntarctic waters of the southern Indian Ocean (between the northern subtropical front and the polar front $10.3 \pm 3.0^{\circ} \mathrm{C}$ ) (Figs. 1, 2). The population-level migratory strategy can be described as being one of longitudinal or dispersive migrations (individuals wintering in the subAntarctic area; $n=12$ ) or long-distance and anticlockwise loop migrations (individuals wintering in subtropical or tropical areas; $n=17$ ). Males tended to migrate more dotted areas) and Kerguelen ( $n=25$, undotted areas), with breeding colonies depicted with red circles

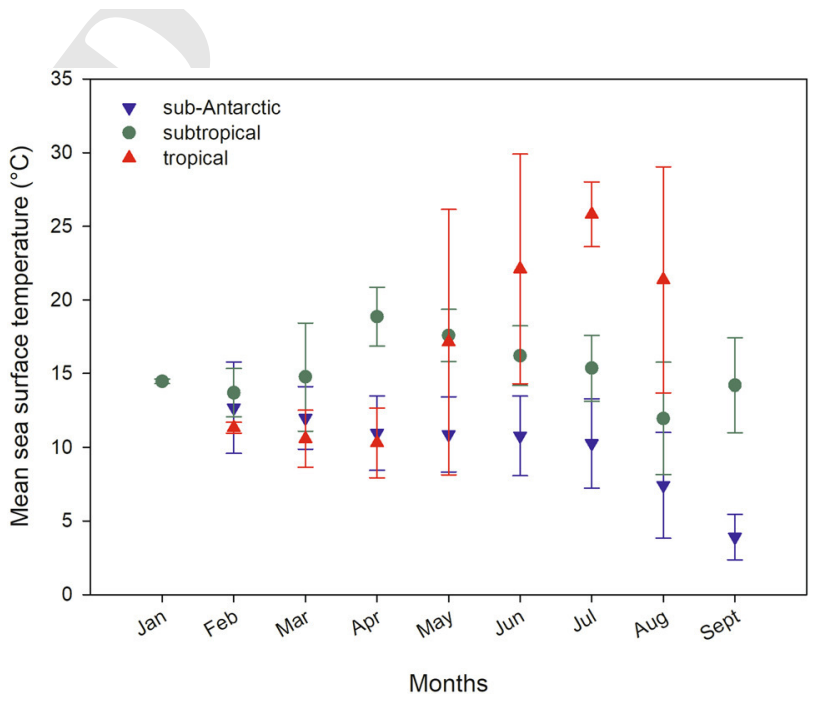

Fig. 2 Monthly sea surface temperatures (recorded by GLS loggers) during the inter-breeding period of brown skuas (Catharacta antarctica lonnbergi) from Crozet and Kerguelen Islands. Wintering grounds are indicated as tropical (red triangle), subtropical (green dots) or sub-Antarctic (inverted blue triangle). Values are mean $\pm \mathrm{SD}$

towards tropical and subtropical waters $(67 \%)$ than females did (47\%; Fig. 3) but differences were not significant (Chi square test, all $p>0.614)$. While birds that wintered in subtropical waters, including coastal waters, left the colony and headed directly to their wintering zones, the birds which targeted tropical areas first moved eastward to subAntarctic staging zones until April-May before reaching their wintering zones (Online Resource Fig S1). In contrast,

\begin{tabular}{|l|ll|} 
Journal : Large 300 & Dispatch : $\mathbf{5 - 7 - 2 0 1 7}$ & Pages : 12 \\
Article No. : $\mathbf{2 1 6 9}$ & $\square$ LE & $\square$ TYPESET \\
MS Code : POBI-D-16-00207 & $\boldsymbol{V}_{\mathrm{CP}}$ & $\boldsymbol{\sim}$ DISK \\
\hline
\end{tabular}




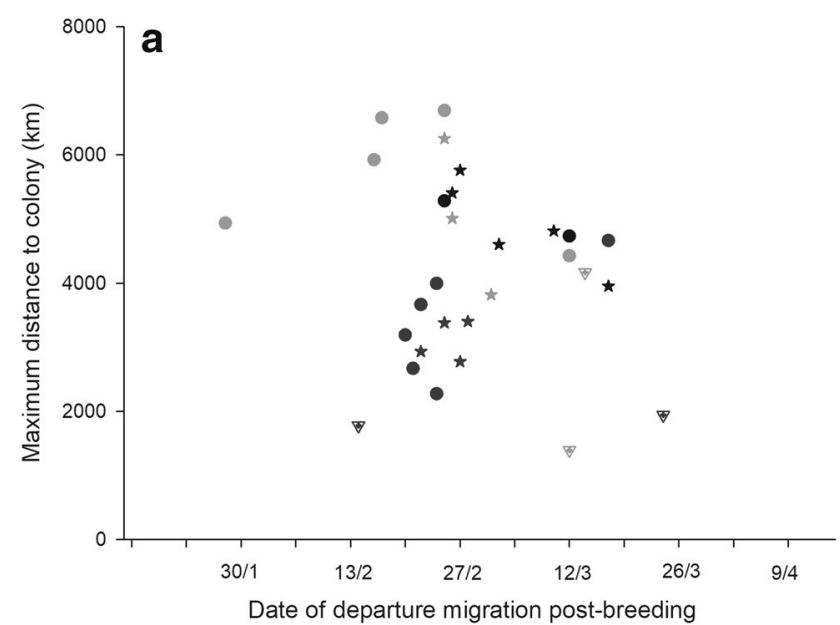

Fig. 3 Maximum distances from the breeding colony reached by individual brown skuas (Catharacta antarctica lonnbergi) from Crozet and Kerguelen during the inter-breeding period versus their departure (upper panel) and arrival (lower panel) dates from and to the breeding sites, respectively. Symbols indicate sex of individuals (dots females, stars males, inverted triangle unknown). Colours

361

362

363

364

365

366

367

368

369

370

371

372 birds that wintered in sub-Antarctic waters mainly moved eastward of the colony to pelagic areas. Irrespective of the wintering zones, it is noteworthy that individuals exhibited high variability in their wintering area (Fig. 1) even within pairs (Online Resource Fig S2a).

Individuals consistently started their post-breeding movements to reach their wintering areas in late Februaryearly March, with a mean departure date around the 1st March (range 28th January-8th April; Table 2). Similarly, skuas consistently left their wintering area for their prebreeding migration in late August with a mean return date around 21st August (range 30th July-24th September). The

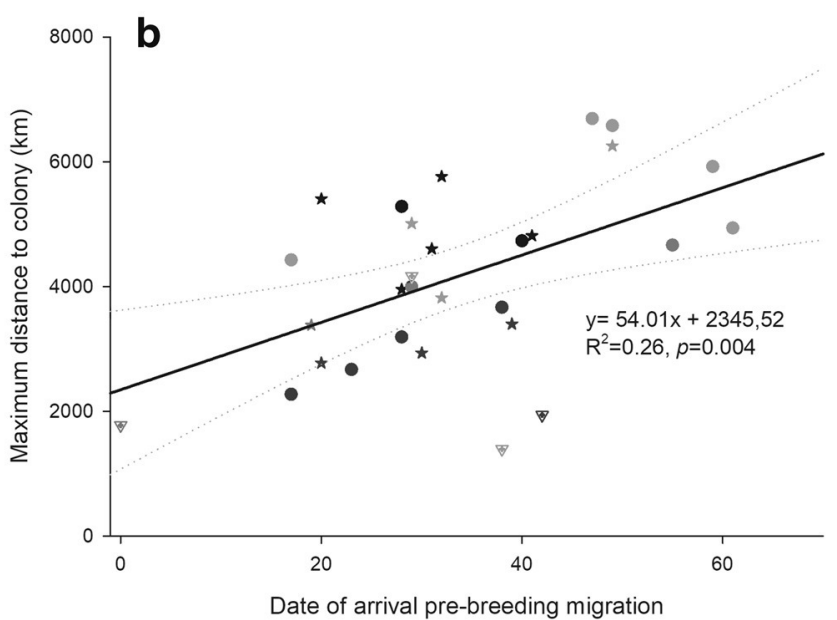

indicate tropical (black), subtropical (grey) or sub-Antarctic (dark grey) wintering grounds. A linear regression (black line) between maximum distances reached and arrival dates at the breeding site (in reference to the earliest date: 4 th August $=$ Day 0), and its $95 \% \mathrm{CI}$ (dotted lines) are indicated

migration dates (outbound or inbound movements) varied between sexes (Table 2; Fig. 3). Females tended to leave earlier and to return later at the breeding sites compared to males. Similarly, the duration of migration substantially differed between the wintering areas and sexes (Table 3; Fig. 3). Contrary to the inbound migration, where brown skuas left their wintering grounds at the same time independently of their wintering areas (21st August), the average outbound migration dates occurred later for birds overwintering in subtropical waters (2nd March vs. 27th February) and migration lasted longer (20 \pm 16 vs. $8 \pm 13$ days; Tables 2, 3) compared to those in southern-
373

374

375

376

377

378

379

380

381

382

383

384

Table 2 Inter-breeding behaviour of brown skuas (Catharacta antarctica lonnbergi) from Crozet and Kerguelen islands

\begin{tabular}{|c|c|c|c|c|c|c|c|c|c|}
\hline \multirow[t]{2}{*}{ Wintering area } & \multirow[t]{2}{*}{ Sex } & \multirow[t]{2}{*}{$n$} & \multicolumn{3}{|c|}{ Outward migration } & \multicolumn{3}{|c|}{ Inward migration } & \multirow{2}{*}{$\begin{array}{l}\text { Wintering } \\
\text { Duration } \\
\text { (days) }\end{array}$} \\
\hline & & & Departure date $^{a}$ & Arrival date ${ }^{b}$ & Duration (days) & Departure date ${ }^{c}$ & Arrival date ${ }^{\mathrm{d}}$ & Duration (days) & \\
\hline \multirow[t]{2}{*}{ Subtropical } & $\mathrm{M}$ & 3 & $27 \mathrm{Feb} \pm 3$ & $2 \mathrm{Apr} \pm 10$ & $34 \pm 13$ & 19 Aug \pm 13 & 9 Sep \pm 11 & $21 \pm 7$ & $140 \pm 3$ \\
\hline & $\mathrm{F}$ & 5 & $19 \mathrm{Feb} \pm 16$ & 14 Mar \pm 32 & $24 \pm 19$ & 27 Aug \pm 10 & 19 Sep \pm 18 & $23 \pm 9$ & $166 \pm 38$ \\
\hline \multirow[t]{2}{*}{ Tropical } & M & 5 & $5 \operatorname{Mar} \pm 8$ & $15 \operatorname{Mar} \pm 12$ & $11 \pm 11$ & 17 Aug \pm 8 & $3 \mathrm{Sep} \pm 8$ & $17 \pm 5$ & $155 \pm 10$ \\
\hline & $\mathrm{F}$ & 2 & $4 \operatorname{Mar} \pm 11$ & $31 \mathrm{Mar} \pm 4$ & $28 \pm 15$ & 11 Aug \pm 15 & 7 Sep \pm 8 & $27 \pm 6$ & $133 \pm 18$ \\
\hline \multirow[t]{2}{*}{ Sub-Antarctic } & M & 4 & $25 \mathrm{Feb} \pm 3$ & $27 \mathrm{Feb} \pm 2$ & $3 \pm 2$ & $24 \mathrm{Aug} \pm 16$ & $31 \mathrm{Aug} \pm 9$ & $6 \pm 9$ & $179 \pm 18$ \\
\hline & $\mathrm{F}$ & 6 & $26 \mathrm{Feb} \pm 10$ & $10 \mathrm{Mar} \pm 18$ & $13 \pm 18$ & 22 Aug \pm 19 & 4 Sep \pm 13 & $13 \pm 10$ & $165 \pm 24$ \\
\hline Total & All & 29 & $29 \mathrm{Feb} \pm 14$ & $15 \operatorname{Mar} \pm 20$ & $15 \pm 16$ & $21 \mathrm{Aug} \pm 13$ & 6 Sep \pm 14 & $16 \pm 10$ & $159 \pm 24$ \\
\hline
\end{tabular}

a Departure date from the breeding site

b Arrival date at the wintering area

c Departure date from the wintering area

d Arrival date at the breeding site

\begin{tabular}{|c|c|c|c|c|}
\hline & Journal : Large 300 & Dispatch : & 5-7-2017 & Pages : 12 \\
\hline & $\begin{array}{l}\text { Article No. : } 2169 \\
\text { MS Code : } \quad \text { POBI-D-16-00207 }\end{array}$ & $\begin{array}{l}\square \text { LE } \\
\boldsymbol{V} \\
\mathrm{CP}\end{array}$ & & $\begin{array}{l}\square \text { TYPESET } \\
\boldsymbol{\sim} \text { DISK }\end{array}$ \\
\hline
\end{tabular}


Table 3 Selected generalized linear models used to test for the effects of sex and wintering area on variation of the migration patterns of brown skuas (Catharacta antarctica lonnbergi) from Crozet and Kerguelen islands

\begin{tabular}{|c|c|c|c|c|c|}
\hline & \multirow[t]{2}{*}{ Independent variables } & \multicolumn{2}{|c|}{ Outward migration } & \multicolumn{2}{|c|}{ Inward migration } \\
\hline & & Departure date ${ }^{a}$ & Duration (days) & Arrival date ${ }^{b}$ & Duration (days) \\
\hline All birds & Sex, area & $\begin{array}{l}\sim \mathrm{Sex} \\
\Delta \mathrm{AIC}=50\end{array}$ & $\begin{array}{l}\sim \mathrm{Sex}+\text { Area }+ \text { Sex. Area } \\
\Delta \mathrm{AIC}=144.5\end{array}$ & $\begin{array}{l}\sim \operatorname{Sex} \\
\Delta \mathrm{AIC}=48.4\end{array}$ & $\begin{array}{l}\sim \mathrm{Sex}+\text { Area }+ \text { Sex.Area } \\
\Delta \mathrm{AIC}=1\end{array}$ \\
\hline
\end{tabular}

Delta AIC ( $\triangle$ AIC) indicates the AIC difference between the selected model and the null model

a Departure date from the breeding site

b Arrival date at the breeding site

385

386

387

388

389

390

391

392

393

394

395

396

397

398

399

400

401

40 RQ1 Resource Fig S3).

\section{Stable isotopes}

404 Feather isotopic values of adult brown skuas from Ker405 guelen Islands ranged widely, from -21.3 to $-15.5 \%$ (a $4065.7 \%$ o difference), and from 7.1 to $16.1 \%$ (9.0\%) for $\delta^{13} \mathrm{C}$ 407 and $\delta^{15} \mathrm{~N}$ values, respectively. Only one adult body feather 408 had isotopic values similar to the chick values, thus veri409 fying that adult feathers did not grow during the breeding 410 period. $\delta^{13} \mathrm{C}$ and $\delta^{15} \mathrm{~N}$ values of feathers from individuals that wintered in different zones were overall significantly different (ANOVA: $F_{(3,80)}=34.8$ and 24.0 for $\delta^{13} \mathrm{C}$ and $\delta^{15} \mathrm{~N}$, respectively, both $p<0.0001$ ) (Table 1). However, both intra- and inter-individual isotopic variations within the same group (sub-Antarctic, subtropical and tropical) were high with large $\delta^{13} \mathrm{C}$ overlaps among groups (Fig. 4). This indicates that most individual birds did not moult all their body feathers in the wintering zone. Rather, individuals moulted over different water masses during the whole inter-nesting period, i.e. during migratory movements and before migration.

Combining GLS data and isotopic values at the feather level depicted a more informative pattern (Fig. 4). Feather $\delta^{13} \mathrm{C}$ and $\delta^{15} \mathrm{~N}$ values from different moulting zones were significantly different (Kruskal-Wallis: $H=55.0$ and 64.3 for $\delta^{13} \mathrm{C}$ and $\delta^{15} \mathrm{~N}$, respectively, both $p<0.0001)$. Post hoc pairwise Conover-Inman tests documented three notable features (Table 1): (i) feather $\delta^{13} \mathrm{C}$ values overall increased with decreasing latitudes, from the lower values of chicks to the higher values of adults that moulted in tropical waters (Madagascar and Java); (ii) feather isotopic values were identical for birds that moulted in western (Madagascar) and eastern (Java) tropical waters of the Indian Ocean; (iii) Feathers of birds that foraged in latitudes between $\sim 35$ and $50^{\circ} \mathrm{S}$ (subtropical and sub-Antarctic) presented remarkably low $\delta^{15} \mathrm{~N}$ values $(8.5 \%$ ) that differed from all the other groups (11.1-14.1\%o).

Table 4 Selected generalized linear mixed models of the variation of the activity patterns of brown skua (Catharacta antarctica lonnbergi) from French Southern Territories

\begin{tabular}{llll}
\hline & Independent variables & Daily proportion of time spent on the water & \\
\cline { 3 - 4 } & & During daytime & During darkness \\
\hline All birds & Sex, month, area & $\sim$ Month:Area, random $=\sim 1$ IID $^{\mathrm{a}}$ & $\sim$ Month:Area, random $=\sim 1$ IID $^{\mathrm{a}}$ \\
& & $\Delta$ AIC $=345.3$ & $\Delta$ AIC $=211$ \\
\hline
\end{tabular}

Delta AIC ( $\triangle \mathrm{AIC})$ indicates the AIC difference between the selected model and the null model

a Including individual as random effect

\begin{tabular}{lll} 
Journal : Large 300 & Dispatch : 5-7-2017 & Pages : 12 \\
Article No. : $\mathbf{2 1 6 9}$ & $\square$ LE & $\square$ TYPESET \\
MS Code : POBI-D-16-00207 & $\boldsymbol{\sim}_{\mathrm{CP}}$ & $\checkmark$ DISK \\
\hline
\end{tabular}




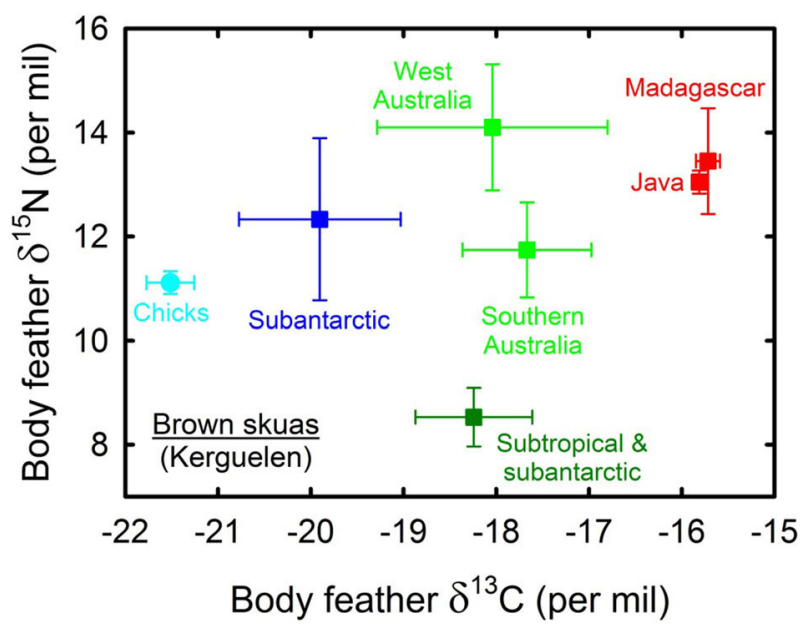

Fig. 4 Body feather $\delta^{15} \mathrm{~N}$ values versus $\delta^{13} \mathrm{C}$ values of adult (squares) and chick (circles) brown skuas (Catharacta antarctica lonnbergi) from Kerguelen Islands according to their moulting zones. Values are mean $\pm \mathrm{SD}$ of all body feathers synthesized within the same habitat (see Table 1)

Females and males from the same pairs $(n=4)$ that 440 were studied over the same inter-breeding period had dif441 ferent feather isotopic values (Mann-Whitney $U$ tests, data 442 not detailed). One pair (blue) differed in their feather $\delta^{13} \mathrm{C}$ 443 values (but not $\delta^{15} \mathrm{~N}$ values), two pairs (green and red) 444 differed in their $\delta^{15} \mathrm{~N}$ values (but not $\delta^{13} \mathrm{C}$ values) and one 445 pair (grey) differed in both their $\delta^{13} \mathrm{C}$ and $\delta^{15} \mathrm{~N}$ values 446 (Online Resource Fig S2).

\section{Discussion}

Using geolocation, we showed that brown skuas from two populations in the southern Indian Ocean tracked in this study migrated northward to overwinter in different areas in the southern hemisphere, remaining in the Indian Ocean $\left(10^{\circ} \mathrm{E}-150^{\circ} \mathrm{E}\right)$, except two individuals that overwintered in the Benguela Current (Atlantic Ocean). Inter-individual variability in migratory strategies was clear, with individuals targeting areas in a continuum from the sub-Antarctic to the tropics.

Long-distance northward migration of brown skuas was long-suspected based on coastal and at-sea resightings and observations (Furness 1987). Brown skuas had long been erroneously reported as migrants in the northern hemisphere until it was clearly established that these reports were misidentifications of south polar skuas (Devillers 1977; Furness 1987). Both brown and south polar skuas are regularly mentioned as visitors in the Northern Indian Ocean during the southern monsoon (Sri Lanka's coastal waters; Van Den Berg et al. 1991; De Silva 2011). Unbanded and formerly misidentified Catharacta birds observed at sea, in large numbers off India or Sri Lanka, as well as museum specimens from the same region, supported the belief that they regularly migrate northward from sub-Antarctic and Antarctic breeding sites. Recent tracking studies suggest that they must be predominantly south polar skuas originating from Antarctic breeding colonies located in the southern Atlantic Ocean sector (Weimerskirch et al. 2015a, b). Our study indicates that some of these birds observed in tropical waters are brown skuas. Timing and migratory patterns of brown skuas appeared similar between the two populations from Kerguelen and Crozet Islands, which concurs with typical return dates of untagged birds at the breeding sites (Paulian 1953; Barré 1976; authors' unpubl. data). Adult brown skuas from both populations principally migrated over the Indian Ocean Basin to overwinter, except for a few individuals that wintered in the very productive Benguela Current System in the eastern Atlantic Ocean. All individuals remained within the southern hemisphere, thus contrasting with the trans-equatorial migrations performed by many individuals of the closely related South Polar skua (Kopp et al. 2011; Weimerskirch et al. 2015a, b). Previous studies on brown skuas from the Southern Atlantic Ocean showed a consistent northward migration to winter within the Argentine Basin, mainly in sub-Antarctic waters (Phillips et al. 2007; Carneiro et al. 2016; Krietsch et al. 2017). Considering recent results (Phillips et al. 2007; Carneiro et al. 2016; Krietsch et al. 2017) and those from this study on the nonbreeding movements of individuals from 4 distant colonies, it appears that brown skuas might winter in a belt around Antarctica, as suggested by Furness (1987). During this period, wintering strategies differ among populations, although variation exists within populations. Single individuals use only a small proportion of the entire nonbreeding range, a pattern that might partly result from competition. Our data show that there was high individual variability in wintering areas among populations, and differences in migratory strategy between sexes.

The population-level migratory strategy of brown skuas can be described as longitudinal or dispersive movements versus long-distance and anticlockwise loop movements (Online Resource Fig S1). Brown skuas targeted neritic or oceanic waters corresponding to three biomes during the nonbreeding period, namely sub-Antarctic, subtropical and tropical waters. Brown skuas avoided the South Subtropical Gyre in the Central Indian Ocean, which corresponds to less productive areas. The wintering grounds correspond to productive dynamic upwelling ecosystems [Benguela Current System or equatorial Eastern Indian Ocean (Chen et al. 2015)] or frontal systems [salinity front southwest of Sumatra (Hunt and Schneider 1987)] and to oligotrophic tropical waters. Some of these zones are important areas for several taxa, specifically seabirds (Le Corre et al. 2012; Delord et al. 2013, 2014). The nonbreeding distribution of 
brown skuas matches areas used by other seabirds such as terns and shearwaters (De Silva 2011; Le Corre et al. 2012). Individual wintering strategies and patterns of winter site fidelity are highly variables among seabird species (Kopp et al. 2011; Tranquilla et al. 2014; Weimerskirch et al. 2015a, b) as shown in great skuas (Stercorarius skua) and brown skuas (Magnusdottir et al. 2012; Krietsch et al. 2016). Brown skuas were recently found to be consistent in their migration strategies and habitat preferences (Carneiro et al. 2016; Krietsch et al. 2017). There were notable differences in migratory routes and wintering areas between individuals as found in other Stercorariidae (Phillips et al. 2007; Weimerskirch et al. 2015a, b) and in other seabird species (Shaffer et al. 2006; Stenhouse et al. 2012; Fijn et al. 2013). These inter-individual differences were not sex-dependent since there was no evidence from tracking that male and female brown skuas segregated during the inter-breeding period, as reported for other Stercorariidae (Magnusdottir et al. 2012). We found carry-over effects (i.e. processes affecting an individual in one season that also affect its subsequent performance) of wintering area on inward migration (duration and early arrival), which may be consistent with selection of early arrival breeding territory, particularly in males. It is not known whether later arrival compromises an individual's ability to re-claim its former breeding territory or reduces its survival. These individual-specific migratory strategies merit further investigation.

Migration and moult are usually separated in time to avoid excessive energy expenditure; the isotopic signature of brown skuas in our study clearly indicated that birds moulted partly in the wintering area, but also probably in area the visited during migration. Stable isotope values indicate that most brown skuas from Kerguelen $(n=11$, $58 \%$ ) moulted their four collected body feathers in different marine habitats that differed from their breeding grounds. This suggests an extended moult of body feathers during the whole nonbreeding period, a strategy also suggested by the feather isotopic values of small Procellariiformes (Cherel et al. 2016). Overall, the skuas' $\delta^{13} \mathrm{C}$ values fit well with the latitudinal $\delta^{13} \mathrm{C}$ gradient in water masses of the Southern Ocean (Cherel and Hobson 2007). Chicks of brown skuas from Mayes, whose diet consist mainly of adult blue petrels that forage in Antarctic waters, showed accordingly low feather $\delta^{13} \mathrm{C}$ values. The values were lower than those from adult birds, thus confirming the GLS data which showed no brown skuas wintering in the Antarctic zone. Feather $\delta^{15} \mathrm{~N}$ values are more difficult to interpret; $\delta^{15} \mathrm{~N}$ baselines vary in different water masses, obscuring the trophic interpretation of $\delta^{15} \mathrm{~N}$. However, the low $\delta^{15} \mathrm{~N}$ values of feathers that grew in mixed subtropicalsub-Antarctic waters are puzzling. Such low feather $\delta^{15} \mathrm{~N}$ values were previously found in smaller numbers in brown skuas from South Georgia (Phillips et al. 2007, 2009) and South Polar skuas when they forage at similar latitudes in the southern Indian Ocean (Weimerskirch et al. 2015a, b). This suggests that skuas fed on low trophic level prey in the area, but this remains to be confirmed. A comparison of the skua $\delta^{15} \mathrm{~N}$ values with those of other sub-Antarctic and subtropical organisms suggests that the unknown prey was not marine mammals, seabirds, cephalopods or fish, but instead macrozooplankton, probably crustaceans (Cherel et al. 2008a, 2010; Stowasser et al. 2012); this hypothesis needs to be thoroughly investigated.

Migratory strategy and foraging during the nonbreeding period between members of breeding pairs is poorly documented in seabirds (Anderson et al. 2009; Mueller et al. 2015; Thiebot et al. 2015). Our results showed that throughout their inter-breeding period, members of the same pairs were spatially segregated (GLS data) and exhibited different foraging habitats and diets (stable isotope values). To the best of our knowledge, the only previous studies on the foraging strategy of pairs of brown skuas focused on the breeding period (Anderson et al. 2009; Carneiro et al. 2014). The results also indicated no sex-related effects on foraging time, habitat use or diet during the nonbreeding period.

Catharacta skuas have diverse feeding techniques and feed on a wide variety of prey (Le Morvan et al. 1967; Barré 1976; Hemmings 1984; Peter et al. 1990; Mougeot et al. 1998). During the breeding season, brown skuas breeding at sub-Antarctic islands show some degree of specialization related to local availability of resources. On Mayes Island at Kerguelen, brown skuas are highly dependent on burrowing petrels and feed mainly on two species, the blue petrel (Halobaena caerulea) and the thinbilled prion (Pachyptila belcheri). At Possession Island, birds rely on rookeries of penguins (Barré 1976; Stahl and Mougin 1986). Migratory patterns appeared to be partly synchronized with the phenology of the skuas' prey (see Online Resource Table S6). The timing of migration of brown skuas coincided with the presence on land and the breeding cycle of their two main prey species. Brown skuas and their prey species arrive and stay at colonies until fledging. A complete shift in foraging ecology and diet between the breeding and nonbreeding period is suspected for skuas, from predation of seabirds on land during the breeding period to exclusively marine during the interbreeding season. This specialization during the breeding season appears not to be maintained outside this period as evidenced by activity pattern and stable isotopic data. There is strong evidence that at least during moulting adult skuas do not rely on small petrels for feeding (Carravieri et al. 2014a). At South Georgia, results suggest a mixed diet of zooplankton and low trophic-level prey over the wintering grounds (Phillips et al. 2007). Compared to south 
polar skuas, brown skuas spent a significantly greater proportion of their time in flight during darkness, indicative of greater search effort in similar wintering grounds (Weimerskirch et al. 2015a, b). Body size might be a factor driving part of this difference in behaviour, as suggested by comparing brown skuas and Falkland skuas (Phillips et al. 2007). Brown skuas are larger than south polar skuas (Furness 1987), suggesting differences in manoeuvrability which might allow different feeding behaviours. To our knowledge there is no study on the foraging habits of brown skuas during migration and winter. Skuas are welldocumented opportunistic kleptoparasites at some times during their annual cycle (Furness 1987). Observations of skuas attacking flocks of seabirds (terns, gulls or shearwaters) and robbing them food (Furness 1987) confirm this seasonal shift in feeding strategy. Brown skuas have been observed attacking seabirds such as white-chinned petrels (Procellaria aequinoctialis) or sooty albatrosses (Phoebetria fusca); KD's pers. obs.) at sea.

The existence of such a variety of migration strategies within brown skua populations is puzzling. Evaluating the demographic correlates as well as the repeatability in individual migratory routes and wintering locations will be valuable to understand this diversity and its fitness consequences. It would be crucial to track the ontogeny of migration strategies, to evaluate heritability and consequences for survival. Identification of carry-over effects in seabird behaviour during the wintering period and identification of their impact on population dynamics (e.g. the effect of winter conditions faced by individual on its subsequent reproduction), should be investigated (Harris et al. 2013). Skuas and other seabird species are good indicators of environmental contaminants (Corsolini et al. 2011; Carravieri et al. 2014a; Goutte et al. 2014). Such individual variability in migratory strategies should also have consequences in terms of susceptibility to environmental stressors such as contaminants and climate change.

Acknowledgments The authors thank many field workers, namely $\mathrm{K}$ Coustaut, N El Ksabi, O Gore, T Gouello, T Lacombe, M Loubon, M Passerault, R Perdriat, A Pérot, B Planade, A Prudor, F Théron. We also thank $S$ Ruault for molecular sexing, M Brault-Favrou for preparing feather samples and G Guillou for running stable isotope analysis. We are grateful to $\mathrm{H}$ Demarcq and P Lehodey for valuable insights into oceanographic characteristics of Indian Ocean. The authors would also like to thank three anonymous referees and D Piepenburg for helpful reviews and constructive suggestions to improve the manuscript. We are grateful to R Reisinger for kindly revising the English of this manuscript. The Ethics Committee of IPEV and Comité Environnement Polaire approved the field procedures. The study was supported by IPEV (programme $\mathrm{N}^{\circ} 109$, PI: H. Weimerskirch), with additional funding from the Prince Albert II de Monaco Foundation and the ANR POLARTOP Program (PI: O Chastel).

\section{References}

Afanasyev V (2004) A miniature daylight level and activity data recorder for tracking animals over long periods. Memoirs Natl Inst Polar Res 58:227-233

Alerstam T, Hedenstrom A, Akesson S (2003) Long-distance migration: evolution and determinants. Oikos 103:247-260

Anderson ORJ, Phillips RA, Shore RF, Mcgill RAR, McDonald RA, Bearhop S (2009) Diet, individual specialisation and breeding of brown skuas (Catharacta antarctica lonnbergi): an investigation using stable isotopes. Polar Biol 32:27-33

Barbraud C, Weimerskirch H (2003) Climate and density shape population dynamics of a marine top predator. Proc R Soc B 270:2111-2116

Barré H (1976) Le Skua subantarctique Stercorarius skua lonnbergi (Mathews) à l'île de la Possession (Iles Crozet). Comité National Français des Recherches Arctiques et Antarctiques 40:77-105

Blanchard P, Hanuise N, Dano S, Weimerskirch H (2007) Offspring sex ratio in relation to parental structural size and body condition in the long-lived wandering albatross (Diomedea exulans). Behav Ecol Sociobiol 61:767-773

Blévin P, Carravieri A, Jaeger A, Chastel O, Bustamente P, Cherel Y (2013) Wide range of mercury contamination in chicks of Southern Ocean seabirds. PLoS ONE 8:e54508

Burnham KP, Anderson DR (2002) Model selection and multimodel inference: a practical information-theoretic approach. Springer, NewYork

Calenge C (2006) The package adehabitat for the R software: a tool for the analysis of space and habitat use by animals. Ecol Model 197:516-519

Carey MJ, Phillips RA, Silk JRD, Shaffer SA (2014) Trans-equatorial migration of Short-tailed Shearwaters revealed by geolocators. Emu 114:352-359

Carneiro APB, Manica A, Phillips RA (2014) Foraging behaviour and habitat use by brown skuas Stercorarius lonnbergi breeding at South Georgia. Mar Biol 161:1755-1764

Carneiro APB, Manica A, Clay TA, Silk JRD, King M, Phillips RA (2016) Consistency in migration strategies and habitat preferences of brown skuas over two winters, a decade apart. Mar Ecol Prog Ser 553:267-281

Carravieri A, Cherel Y, Blévin P, Brault-Favrou M, Chastel O, Bustamante P (2014a) Mercury exposure in a large subantarctic avian community. Environ Pollut 190:51-57

Carravieri A, Bustamante P, Churlaud C, Fromant A, Cherel Y (2014b) Moulting patterns drive within-individual variations of stable isotopes and mercury in seabird body feathers: implications for monitoring of the marine environment. Mar Biol 161:963-968

Chen G, Han W, Li Y, Wang D, Shinoda T (2015) Intraseasonal variability of upwelling in the equatorial Eastern Indian Ocean. J Geophys Res-Ocean 120:7598-7615

Cherel Y, Hobson KA (2007) Geographical variation in carbon stable isotope signatures of marine predators: a tool to investigate their foraging areas in the Southern Ocean. Mar Ecol Prog Ser 329:281-287

Cherel Y, Ducatez S, Fontaine C, Richard P, Guinet C (2008a) Stable isotopes reveal the trophic position and mesopelagic fish diet of female southern elephant seals breeding on the Kerguelen Islands. Mar Ecol Prog Ser 370:239-247

Cherel Y, Le Corre M, Jaquemet S, Menard F, Richard P, Weimerskirch H (2008b) Resource partitioning within a tropical seabird community: new information from stable isotopes. Mar Ecol Prog Ser 366:281-291
682

683

684

685

686

687

688

689

690

691

692

693

694

695

696

697

698

699

700

701

702

703

704

705

706

707

708

709

710

711

712

713

714

715

716

717

718

719

720

721

722

723

724

725

726

727

728

729

730

731

732

733

\begin{tabular}{|c|c|c|c|c|}
\hline & Journal : Large $\mathbf{3 0 0}$ & Dispatch & 5-7-2017 & Pages: \\
\hline & $\begin{array}{l}\text { Article No. : } 2169 \\
\text { MS Code : } \quad \text { POBI-D-16-00207 }\end{array}$ & $\begin{array}{r}\square \\
\mho_{\mathrm{CP}}^{\mathrm{LE}} \\
\end{array}$ & & $\begin{array}{ll}\square & \text { TYPESET } \\
\Downarrow & \text { DISK } \\
\end{array}$ \\
\hline
\end{tabular}


Cherel Y, Fontaine C, Richard P, Labat JP (2010) Isotopic niches and trophic levels of myctophid fishes and their predators in the Southern Ocean. Limnol Oceanogr 55:324-332

Cherel Y, Connan M, Jaeger A, Richard P (2014) Seabird year-round and historical feeding ecology: blood and feather delta C-13C and delta $\mathrm{C}-15 \mathrm{~N}$ values document foraging plasticity of small sympatric petrels. Mar Ecol Prog Ser 505:267-280

Cherel Y, Quillfeldt P, Delord K, Weimerskirch H (2016) Combination of at-sea activity, geolocation and feather stable isotopes documents where and when seabirds molt. Front Ecol Environ 4:1-16

Corsolini S, Borghesi N, Ademollo N, Focardi S (2011) Chlorinated biphenyls and pesticides in migrating and resident seabirds from East and West Antarctica. Environ Int 37:1329-1335

De Silva RI (2011) Observing oceanic birds in Sri Lanka. Indian Birds 7:58-62

Delord K, Barbraud C, Bost C A, Cherel Y, Guinet C, Weimerskirch $\mathrm{H}$ (2013) Atlas of top predators from the French Southern Territories in the Southern Indian Ocean. doi: 10.15474/ AtlasTopPredatorsOI_CEBC.CNRS_FrenchSouthernTerritories, 1-252. http://www.cebc.cnrs.fr/ecomm/Fr_ecomm/ecomm_ecor_ OI1.html. Accessed 28 Oct 2016

Delord K, Barbraud C, Bost CA, Deceuninck B, Lefebvre T, Lutz R, Micol T, Phillips RA, Trathan PN, Weimerskirch H (2014) Areas of importance for seabirds tracked from French southern territories, and recommendations for conservation. Mar Policy 48:1-13

Devillers P (1977) The skuas of the north american pacific coast. Auk 94:417-429

Dias MP, Granadeiro JP, Phillips RA, Alonso H, Catry P (2011) Breaking the routine: individual Cory's shearwaters shift winter destinations between hemispheres and across ocean basins. Proc R Soc B 278:1786-1793

Egevang C, Stenhouse IJ, Phillips RA, Petersen A, Fox JW, Silk JRD (2010) Tracking of Arctic terns Sterna paradisaea reveals longest animal migration. Proc Natl Acad Sci USA 107(5):2078-2081. doi:10.1073/pnas.0909493107

Eklund CR (1961) Distribution and life history studies of the Southpolar skua. Bird 32:187-223

Fijn RC, Hiemstra D, Phillips RA, van der Winden J (2013) Arctic Terns Sterna paradisaea from The Netherlands migrate record distances across three oceans to Wilkes Land, East Antarctica. Ardea 101:3-12

Frederiksen M, Daunt F, Harris MP, Wanless S (2008) The demographic impact of extreme events: stochastic weather drives survival and population dynamics in a long-lived seabird. J Anim Ecol 77:1020-1029

Frederiksen M, Moe B, Daunt F, Phillips RA, Barrett RT, Bogdanova MI, Boulinier T, Chardine JW, Chastel O, Chivers LS, Christensen-Dalsgaard S, Clement-Chastel C, Colhoun K, Freeman R, Gaston AJ, Gonzalez-Solis J, Goutte A, Gremillet D, Guilford T, Jensen GH, Krasnov Y, Lorentsen SH, Mallory ML, Newell M, Olsen B, Shaw D, Steen H, Strom H, Systad GH, Thorarinsson TL, Anker-Nilssen T (2012) Multicolony tracking reveals the winter distribution of a pelagic seabird on an ocean basin scale. Divers Distrib 18:530-542

Furness RW (1987) The skuas. T. \& A. D. Poyser, Calton

Gonzalez-Solis J, Croxall JP, Oro D, Ruiz X (2007) Trans-equatorial migration and mixing in the wintering areas of a pelagic seabird. Front Ecol Environ 5:297-301

Goutte A, Bustamante P, Barbraud C, Delord K, Weimerskirch H, Chastel O (2014) Demographic responses to mercury exposure in two closely related Antarctic top predators. Ecology 95:1075-1086

Graña Grilli M, Cherel Y (2017) Skuas (Stercorarius spp.) moult body feathers during both the breeding and inter-breeding periods: implications for stable isotope investigations in seabirds. Ibis 159(2):266-271

Guilford T, Meade J, Willis J, Phillips R, Boyle D, Roberts S, Collett M, Freeman R, Perrins CM (2009) Migration and stopover in a small pelagic seabird, the Manx shearwater Puffinus puffinus: insights from machine learning. Proc R Soc B 276:1215-1223. doi:10.1098/rspb.2008.1577

Harris MP, Daunt F, Bogdanova MI, Lahoz-Monfort JJ, Newell MA, Phillips RA, Wanless S (2013) Inter-year differences in survival of Atlantic puffins Fratercula arctica are not associated with winter distribution. Mar Biol 160:2877-2889

Hedd A, Montevecchi WA, Otley H, Phillips RA, Fifield DA (2012) Trans-equatorial migration and habitat use by sooty shearwaters Puffinus griseus from the South Atlantic during the nonbreeding season. Mar Ecol Prog Ser 449:277-290

Hedd A, Montevecchi WA, Phillips RA, Fifield DA (2014) Seasonal sexual segregation by monomorphic sooty shearwaters Puffinus griseus reflects different reproductive roles during the pre-laying period. PLoS ONE 9:e85572. doi:10.1371/journal.pone.0085572

Hemmings AD (1984) Aspects of the breeding biology of McCormick's skua Catharacta maccormicki at Signy Island, South Orkney Islands. Br Antarct Surv Bull 65:65-79

Higgins PJ, Davies SJJF (1996) Handbook of Australian, New Zealand and Antarctic birds: vol. III: snipes to pigeons. Oxford University Press, Oxford

Hunt GL, Schneider DC (1987) Scale-dependent processes in the physical and biological environment of marine birds. Seabirds: feeding ecology and role in marine ecosystems. Cambridge University Press, Cambridge

Jaeger A, Blanchard P, Richard P, Cherel Y (2009) Using carbon and nitrogen isotopic values of body feathers to infer inter- and intraindividual variations of seabird feeding ecology during moult. Mar Biol 156:1233-1240

Jessopp MJ, Cronin M, Doyle TK, Wilson M, McQuatters-Gollop A, Newton S, Phillips RA (2013) Transatlantic migration by postbreeding puffins: a strategy to exploit a temporarily abundant food resource? Mar Biol 160:2755-2762

Kopp M, Peter HU, Mustafa O, Lisovski S, Ritz MS, Phillips RA, Hahn S (2011) South polar skuas from a single breeding population overwinter in different oceans though show similar migration patterns. Mar Ecol Prog Ser 435:263-267

Krietsch J, Hahn S, Kopp M, Phillips RA, Peter HU, Lisovski S (2017) Consistent variation in individual migration strategies of brown skuas. Mar Ecol Prog Ser. doi:10.3354/meps11932

Lack D (1968) Bird migration and natural selection. Oikos 19:1-9

Lascelles B, Di Sciara GN, Agardy T, Cuttelod A, Eckert S, Glowka L, Hoyt E, Llewellyn F, Louzao M, Ridoux V, Tetley MJ (2014) Migratory marine species: their status, threats and conservation management needs. Aquat Conserv Mar Freshw Ecosyst 24:111-127

Le Corre M, Jaeger A, Pinet P, Kappes MA, Weimerskirch H, Catry T, Ramos JA, Russell JC, Shah N, Jaquemet S (2012) Tracking seabirds to identify potential Marine Protected Areas in the tropical western Indian Ocean. Biol Conserv 156:83-93

Le Morvan P, Mougin JL, Prevost J (1967) Ecologie du Skua antarctique (Stercorarius skua maccormicki) dans l'archipel de Pointe Géologie (Terre Adélie). L'Oiseau et $\mathrm{R}$ F $\mathrm{O}$ 37(3):193-200

Leat EHK, Bourgeon S, Magnusdottir E, Gabrielsen GW, Grecian WJ, Hanssen SA, Olafsdottir K, Petersen A, Phillips RA, Strom H, Ellis S, Fisk AT, Bustnes JO, Furness RW, Borgå K (2013) The influence of wintering area on concentration and pattern of persistent organic pollutants in a breeding migratory seabird. Mar Ecol Prog Ser 491:277-293

Longhurst AR (2007) Ecological geography of the sea. Elsevier Academic Press, London 
Magnusdottir E, Leat EHK, Bourgeon S, Strom H, Petersen A, Phillips RA, Hanssen SA, Bustnes JO, Hersteinsson P, Furness RW (2012) Wintering areas of Great Skuas Stercorarius skua breeding in Scotland, Iceland and Norway. Bird Study 59:1-9

Maree BA, Wanless RM, Fairweather TP, Sullivan BJ, Yates O (2014) Significant reductions in mortality of threatened seabirds in a South African trawl fishery. Anim Conserv 17:520-529

Montevecchi W, Fifield D, Burke C, Garthe S, Hedd A, Rail JF, Robertson G (2012a) Tracking long-distance migration to assess marine pollution impact. Biol Lett 8:218-221

Montevecchi WA, Hedd A, McFarlane Tranquilla L, Fifield DA, Burke CM, Regular PM, Davoren GK, Garthe S, Robertson GJ, Phillips RA (2012b) Tracking seabirds to identify ecologically important and high risk marine areas in the western North Atlantic. Biol Conserv 156:62-71

Mougeot F, Genevois F, Bretagnolle V (1998) Predation on burrowing petrels by the brown shua (Catharacta skua lönnbergi) at Mayes Island, Kerguelen. J Zool 244:429-439

Mueller MS, Massa B, Phillips RA, Dell'Omo G (2015) Seabirds mated for life migrate separately to the same places: behavioural coordination or shared proximate causes? Anim Behav 102:267-276

Olsen KM, Larsson H (1997) Skuas and jaegers: a guide to the skuas and jaegers of the world. Pica Press ed, Mountfield

Paulian P (1953) Pinnipèdes, cétacés, oiseaux des iles Kerguelen et Amsterdam. Mem Inst Scientifique de Madagascar 8:111-235

Péron C, Delord K, Phillips RA, Charbonnier Y, Marteau C, Louzao M, Weimerskirch H (2010) Seasonal variation in oceanographic habitat and behaviour of white-chinned petrels Procellaria aequinoctialis from Kerguelen Island. Mar Ecol Prog Ser 416:267-284

Peter HU, Kaiser M, Gebauer A (1990) Ecological and morphological investigations on south polar Skuas (Catharacta maccormicki) and brown Skuas (C. skua lonnbergi) on Fildes peninsula, King George Island, South Shetland Islands. Zool Jb Syst 117:201-218

Phillips RA, Xavier JC, Croxall JP, Burger AE (2003) Effects of satellite transmitters on albatrosses and petrels. Auk 120:1082-1090

Phillips RA, Silk JRD, Croxall JP, Afanasyev V, Briggs DR (2004) Accuracy of geolocation estimates for flying seabirds. Mar Ecol Prog Ser 266:265-272

Phillips R, Silk JRD, Croxall JP, Afanasyev V, Bennett VJ (2005) Summer distribution and migration of nonbreeding albatrosses: individual consistencies and and implications for conservation. Ecology 86:2386-2396

Phillips RA, Catry P, Silk JRD, Bearhop S, McGill R, Afanasyev V, Strange IJ (2007) Movements, winter distribution and activity patterns of Falkland and brown skuas: insights from loggers and isotopes. Mar Ecol Prog Ser 345:281-291

Phillips R, Bearhop S, Mcgill R, Dawson D (2009) Stable isotopes reveal individual variation in migration strategies and habitat preferences in a suite of seabirds during the nonbreeding period. Oecologia 160:795-806

Rayner MJ, Hauber ME, Steeves TE, Lawrence HA, Thompson DR, Sagar PM, Bury SJ, Landers TJ, Phillips RA, Ranjard L, Shaffer SA (2011) Contemporary and historical separation of transequatorial migration between genetically distinct seabird populations. Nat Commun. doi:10.1038/ncomms1330

Reiertsen TK, Erikstad KE, Anker-Nilssen T, Barrett RT, Boulinier T, Frederiksen M, Gonzalez-Solis J, Gremillet D, Johns D, Moe B, Ponchon A, Skern-Mauritzen M, Sandvik H, Yoccoz NG (2014) Prey density in non-breeding areas affects adult survival of black-legged kittiwakes Rissa tridactyla. Mar Ecol Prog Ser 509:289-302

Shaffer SA, Tremblay Y, Weimerskirch H, Scott D, Thompson DR, Sagar PM, Moller H, Taylor GA, Foley DG, Block BA, Costa DP (2006) Migratory shearwaters integrate oceanic resources across the Pacific Ocean in an endless summer. Proc Natl Acad Sci USA 103:12799-12802

Stahl JC, Mougin JL (1986) La ségrégation alimentaire chez le Skua subantarctique Stercorarius skua lönnbergi dans l'archipel Crozet. L'Oiseau et R F O 56:193-208

Stenhouse IJ, Egevang C, Phillips RA (2012) Trans-equatorial migration, staging sites and wintering area of Sabine's Gulls Larus sabini in the Atlantic Ocean. Ibis 154:42-51

Stowasser G, Atkinson A, McGill R, Phillips RA, Collins MA, Pond DW (2012) Food web dynamics in the Scotia Sea in summer: a stable isotope study. Deep-Sea Res 59-60:208-221

Thiebot JB, Authier M, Trathan PN, Bost CA (2014) Gentlemen first? 'Broken stick' modelling reveals sex-related homing decision date in migrating seabirds. J Zool 292:25-30

Thiebot JB, Bost CA, Dehnhard N, Demongin L, Eens M, Lepoint G, Cherel Y, Poisbleau M (2015) Mates but not sexes differ in migratory niche in a monogamous penguin species. Biol Lett 11:20150429. doi:10.1098/rsbl.2015.0429

Tranquilla LAM, Montevecchi WA, Fifield DA, Hedd A, Gaston AJ, Robertson GJ, Phillips RA (2014) Individual Winter Movement Strategies in Two Species of Murre (Uria spp.) in the Northwest Atlantic. PLoS ONE 9(4):e90583. doi:10.1371/journal.pone. 0090583

Van Den Berg AB, Smeenk C, Bosman CW, Haase BJ, Van Der Niet AM, Cadée GC (1991) Barau's Petrel Pterodroma baraui, Jouanin's Petrel Bulweria fallax and other seabirds in the northern indian ocean in June-July 1984 and 1985. Ardea 79:1-14

Visser ME, Both C (2005) Shifts in phenology due to global climate change: the need for a yardstick. Proc R Soc Lond B 272:2561-2569

Watkins BP, Petersen SL, Ryan PG (2008) Interactions between seabirds and deep-water hake trawl gear: an assessment of impacts in South African waters. Anim Conserv 11:247-254

Weimerskirch H, Louzao M, de Grissac S, Delord K (2012) Changes in wind pattern alter albatross distribution and life-history traits. Science 335:211-214

Weimerskirch H, Cherel Y, Delord K, Jaeger A, Patrick SC, RiotteLambert L (2014) Lifetime foraging patterns of the wandering albatross: life on the move! J Exp Mar Biol Ecol 450:68-78

Weimerskirch H, Tarroux A, Chastel O, Delord K, Cherel Y, Descamps S (2015a) Population-specific wintering distributions of adult south polar skuas over the three oceans. Mar Ecol Prog Ser 538:229-237

Weimerskirch H, Delord K, Guitteaud A, Phillips RA, Pinet P (2015b) Extreme variation in migration strategies between and within wandering albatross populations during their sabbatical year, and their fitness consequences. Sci Rep 5:8853

Wilson RP, Ducamp JJ, Rees G, Culik BM, Niekamp K (1992) Estimation of location: global coverage using light intensity. In: Priede IMSS (ed) Wildlife telemetry: remote monitoring and tracking of animals. Ellis Horward, Chichester

Yamamoto T, Takahashi A, Katsumata N, Sato K, Trathan PN (2010) At-Sea Distribution and Behavior of Streaked Shearwaters (Calonectris Leucomelas) During the Nonbreeding Period. Auk 127:871-881

\begin{tabular}{|l|lll|}
\hline & Journal : Large 300 & Dispatch : $\mathbf{5 - 7 - 2 0 1 7}$ & Pages : $\mathbf{1 2}$ \\
& Article No. : 2169 & $\square$ & $\square$ \\
MS Code : POBI-D-16-00207 & $\boldsymbol{\sim}_{\mathrm{CP}}^{\text {TYPESET }}$ & $\boldsymbol{\sim}_{\text {DISK }}$ \\
\hline
\end{tabular}


Journal : 300

Article : 2169

\section{Author Query Form}

算 Springer

the language of science

\section{Please ensure you fill out your response to the queries raised below and return this form along with your corrections}

\section{Dear Author}

During the process of typesetting your article, the following queries have arisen. Please check your typeset proof carefully against the queries listed below and mark the necessary changes either directly on the proof/online grid or in the 'Author's response' area provided below

\begin{tabular}{|l|l|l|}
\hline Query & Details Required & Author's Response \\
\hline AQ1 & $\begin{array}{l}\text { References (British Antarctic Survey 2009, Zuur et al. 2010, R Development Core Team 2013, Krietsch } \\
\text { et al. 2016) were mentioned in the manuscript; however, these were not included in the reference list. As a } \\
\text { rule, all mentioned references should be present in the reference list. Please provide the reference details } \\
\text { to be inserted in the reference list. }\end{array}$ & $\begin{array}{l}\text { Reference (Lascelles 2014) was provided in the reference list; however, this was not mentioned or cited in } \\
\text { the manuscript. As a rule, if a citation is present in the text, then it should be present in the list. Please } \\
\text { provide the location of where to insert the reference citation in the main body text. }\end{array}$ \\
\hline AQ2 & \\
\hline
\end{tabular}

